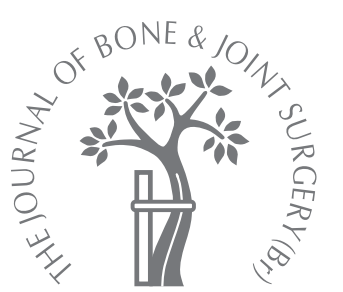

R. Malhotra,

S. Bhan,

E. Krishna Kiran

From the All India

Institute of Medical

Sciences, New Delhi, India
R. Malhotra, MS, Additional Professor S. Bhan, MS, FRCS Professor and Head

E. Krishna Kiran, MS, Senior Resident

Department of Orthopaedics All India Institute of Medical Sciences, Ansari Nagar, New Delhi 110029, India.

Correspondence should be sent to Dr R. Malhotra;

e-mail:

rmalhotra62@hotmail.com

C2005 British Editorial Society of Bone and Joint Surgery

doi:10.1302/0301-620X.87B11. $16836 \$ 2.00$

$J$ Bone Joint Surg [Br] 2005;87-B:1549-52.

Received 13 June 2005;

Accepted 6 July 2005

\title{
Haemarthroses after total knee arthroplasty caused by an isolated platelet factor 3 availability defect
}

\begin{abstract}
We present seven patients with recurrent haemarthroses after total knee arthroplasty, caused by an inherent platelet function defect. These patients developed painful knee swelling, persistent bleeding and/or wound breakdown, a platelet factor 3 availability defect being identified in all cases. Surgical exploration, with joint debridement, lavage and synovectomy, was performed in four patients who did not improve with conservative therapy. Histopathological examination of synovium revealed a focal synovial reaction with histiocytic infiltration, and occasional foreign-body giant cells. One patient required an early revision because of aseptic loosening of their tibial component. The condition was treated by single-donor platelet transfusions with good results. The diagnosis, management, and relevance of this disorder are discussed.
\end{abstract}

Spontaneous, recurrent haemarthrosis has been reported as a complication in less than $1 \%$ of total knee arthroplasties (TKAs). ${ }^{1-3}$ It often presents as a diagnostic and therapeutic challenge and there is a lack of literature on the condition. The causes of a recurrent haemarthrosis are not well defined but the most common cause is believed to be the entrapment of either synovial tissue or the fat pad between prosthetic surfaces. ${ }^{4}$ Other causes include metalinduced synovitis, ${ }^{5-9}$ and abnormal coagulation in the post-operative period from either disease or medication, which may account for approximately one-third of cases reported in the literature. ${ }^{10}$ An identifiable cause is not found in more than $50 \%$ of cases. ${ }^{4}$ We present a study of recurrent haemarthroses after TKA caused by an intrinsic platelet function defect and its management.

\section{Patients and Methods}

Between 1994 and 2002, 1247 primary TKAs were performed at our hospital. Of these, 12 patients presented with recurrent haemarthroses. Five were known haemophiliacs, the haemarthroses were related to falls in serum factor VIII levels and responded to factor VIII infusions. The remaining seven patients, who had no known coagulation disorder, formed the basis of this study. The NexGen TKA (Zimmer, Warsaw, Indiana) was used in six patients and the Natural Knee (Centerpulse, Baar, Switzerland) in one. All patients received prophylactic antibiotics and thromboprophylaxis using low-molecular-weight heparin (enoxaparin 20 to $40 \mathrm{mg}$ subcutaneously depending upon the patient's weight). Closed suction drainage was used in all patients and was removed 48 hours after surgery. Cryotherapy was routinely used post-operatively in order to reduce analgesic requirement and to control local swelling.

The haemarthroses were associated with wound breakdown and/or persistent bleeding from the wound. If a haemarthrosis occurred, anticoagulants were stopped and all patients were treated expectantly with rest, elevation, a compressive dressing and cryotherapy. A full history was taken, and investigations performed, to exclude renal disease, heart disease, liver dysfunction or the administration of any medication which might affect platelet function (anticoagulants, aspirin, non-steroidal anti-inflammatory drugs, disease-modifying antirheumatic drugs). ${ }^{11-14}$ If the haemarthrosis did not resolve, a full coagulation profile was performed including prothrombin time, activated partial thromboplastin time, clot stability and total platelet counts. ${ }^{15,16}$ If these were normal, further evaluation of platelet function was undertaken, including bleeding time, prothrombin consumption index, measurement of von Willebrand factor levels, platelet factor 3 (PF3) availability and platelet aggregation studies. ${ }^{17}$ The total PF3 was measured by the method of Kasturi, Saraya and Ramkishan. ${ }^{18}$ PF3 availability was measured by using the method of Hardisty and Hutton. ${ }^{19}$ This mea- 
Table I. Clinical profile of seven patients with recurrent haemarthroses because of platelet factor 3 availability defect

\begin{tabular}{|c|c|c|c|c|c|c|c|c|c|c|c|c|c|c|}
\hline $\begin{array}{l}\text { Patient } \\
\text { number }\end{array}$ & $\begin{array}{l}\text { Age } \\
\text { (yrs) }\end{array}$ & Gender* & Diagnosis $^{\dagger}$ & $\begin{array}{l}\text { Pre- } \\
\text { operative } \\
\text { KSS } \\
\text { (objective; } \\
100 \text { points) }\end{array}$ & $\begin{array}{l}\text { Pre- } \\
\text { operative } \\
\text { KSS } \\
\text { (functional; } \\
100 \text { points) }\end{array}$ & $\begin{array}{l}\text { Pre- } \\
\text { operative } \\
\text { ROM§ ( }\left(^{\circ}\right)\end{array}$ & $\begin{array}{l}\text { Prosthesis } \\
\text { used }\end{array}$ & Complications & $\begin{array}{l}\text { Repeat } \\
\text { surgery }\end{array}$ & $\begin{array}{l}\text { Length } \\
\text { of } \\
\text { hospital } \\
\text { stay } \\
\text { (days) }\end{array}$ & $\begin{array}{l}\text { Post- } \\
\text { operative } \\
\left.\text { ROM ( }{ }^{\circ}\right)\end{array}$ & $\begin{array}{l}\text { Post- } \\
\text { operative } \\
\text { KSS } \\
\text { (objective; } \\
100 \text { points) }\end{array}$ & $\begin{array}{l}\text { Post- } \\
\text { operative } \\
\text { KSS } \\
\text { (functional; } \\
100 \text { points) }\end{array}$ & $\begin{array}{l}\text { Follow- } \\
\text { up (yrs) }\end{array}$ \\
\hline 1 & 56 & $M$ & OA & 38 & 60 & 20 to 100 & NexGen & $\begin{array}{l}\text { Haematoma } \\
\text { with wound } \\
\text { breakdown; } \\
\text { aseptic loosen- } \\
\text { ing of tibial } \\
\text { component at } \\
18 \text { months }\end{array}$ & $\begin{array}{l}\text { Debridement } \\
\text { and drainage } \\
\text { of haematoma; } \\
\text { tibial compo- } \\
\text { nent revision } \\
\text { with stem } \\
\text { extension }\end{array}$ & 21 & 10 to 95 & 74 & 75 & 3 \\
\hline 2 & 47 & $\mathrm{~F}$ & RA & 48 & 50 & 0 to 90 & $\begin{array}{l}\text { Natural } \\
\text { knee }\end{array}$ & $\begin{array}{l}\text { Superficial skin } \\
\text { necrosis with } \\
\text { wound break- } \\
\text { down }\end{array}$ & $\begin{array}{l}\text { Debridement } \\
\text { (twice) of lower } \\
\text { part of wound }\end{array}$ & 33 & 0 to 95 & 84 & 70 & 4 \\
\hline 3 & 79 & $M$ & OA & 12 & 55 & 15 to 100 & NexGen & $\begin{array}{l}\text { Persistent } \\
\text { bleeding from } \\
\text { the wound }\end{array}$ & $\begin{array}{l}\text { None } \\
\text { (conservative } \\
\text { management) }\end{array}$ & 14 & 0 to 95 & 89 & 70 & 2 \\
\hline 4 & 67 & $\mathrm{~F}$ & OA & 45 & 60 & 10 to 110 & NexGen & $\begin{array}{l}\text { Wound } \\
\text { breakdown }\end{array}$ & $\begin{array}{l}\text { None } \\
\text { (conservative } \\
\text { management) }\end{array}$ & 17 & 0 to 90 & 88 & 75 & 5 \\
\hline 5 & 59 & $M$ & OA & 42 & 60 & 0 to 110 & NexGen & $\begin{array}{l}\text { Wound } \\
\text { breakdown }\end{array}$ & $\begin{array}{l}\text { Debridement/ } \\
\text { joint wash-out }\end{array}$ & 21 & 5 to 105 & 84 & 70 & 6 \\
\hline 6 & 68 & $\mathrm{~F}$ & RA & 38 & 50 & 15 to 95 & NexGen & $\begin{array}{l}\text { Wound } \\
\text { breakdown }\end{array}$ & $\begin{array}{l}\text { Debridement/ } \\
\text { joint wash-out } \\
\text { twice }\end{array}$ & 29 & 10 to 90 & 87 & 75 & 3 \\
\hline 7 & 62 & $\mathrm{~F}$ & OA & 18 & 50 & 10 to 100 & NexGen & $\begin{array}{l}\text { Persistent } \\
\text { bleeding from } \\
\text { the wound }\end{array}$ & $\begin{array}{l}\text { None } \\
\text { (conservative } \\
\text { management) }\end{array}$ & 19 & 0 to 90 & 88 & 75 & 4 \\
\hline
\end{tabular}

${ }^{*} \mathrm{M}$, male; $\mathrm{F}$, female

† OA, osteoarthritis; RA, rheumatoid arthritis

‡ KSS, Knee Society score ${ }^{21}$

$\S \mathrm{ROM}$, range of movement

sures the Russell viper venom time on the platelet-rich plasma of the patient at 0 and 20 minutes after incubation with adenosine 5 ' -diphosphate (ADP). PF3 availability was considered to be reduced when the Russell viper venom time was greater than 19.0 seconds. $^{20}$ Patients who had normal platelet aggregation and PF3 content, but reduced PF3 availability, were diagnosed as having an isolated PF3 availability defect. Exploration and drainage of the knee was performed if a haematoma was large, tense and painful, or in cases of swelling with signs of impending skin necrosis, or when there was no response to immobilisation and expectant treatment. Synovectomy was always performed at exploration and tissue sent for histopathological examination and culture.

Once the diagnosis of a PF3 availability defect was made, patients were treated with single-donor platelet transfusions. This resulted in a rapid reduction in knee swelling in all patients. Inquiries were made about any family or personal history of minor bleeding disorders, in the form of bruising or ecchymoses, after a diagnosis of a PF3 availability defect was confirmed. Two patients admitted to a parental history of such a defect.

\section{Results}

There were three men and four women, with a mean age of 62.6 years (47 to 79 ). The left knee was replaced in four patients. The primary diagnosis was osteoarthritis in five patients and rheumatoid arthritis in two. The mean length of follow-up was 3.6 years (2 to 6).

The mean time interval between TKA and the first haemarthrosis was five weeks (10 days to 12 weeks) while the interval between the haemarthroses ranged from three days to three months. The mean number of haemarthroses before the diagnosis of PF3 availability defect, and its specific treatment, was 2.8 (2 to 5). No patient had a recurrence of haemarthrosis after the diagnosis was made and treatment was instituted with platelet transfusion. Delayed wound healing was seen in all patients, with superficial skin necrosis in two. Surgical exploration was required in four patients (twice in two patients) and split-thickness skin grafting in one. The mean time from TKA to repeat surgery was 12 days (7 to 14). Extensive synovial proliferation was seen in all patients at exploration. Histopathological examination of the synovium revealed focally-reactive synovium with histiocytic infiltration and occasional foreign-body giant cells. Significant haemosiderin deposition was seen in those patients with multiple recurrences. Cultures from the joint fluid and the synovium did not grow any organisms. One patient, who developed the first haemarthrosis ten days after TKA, had four recurrences before the diagnosis was made. This patient also had early loosening of the tibial component within 18 months of surgery. After revision of the tibial component under the cover of single donor platelet transfusion, there were no further bleeding complications.

The mean pre-operative Knee Society objective score ${ }^{21}$ was 34.4 (12 to 48 ) and the mean pre-operative functional score was 57.1 (50 to 60 ); these improved to 84.9 (74 to 89 ) and 72.6 (70 to 75$)$, respectively at the last follow-up. All patients except one lost some movement compared with their pre-operative range. The mean length of the hospital stay was 22 days (14 to 33 ). The clinical profile of all the patients is summarised in Table I. 


\section{Discussion}

Haemarthrosis and haematoma formation after TKA can lead to persistent wound drainage, ${ }^{22}$ and can adversely affect wound healing. The breakdown products of haemoglobin are toxic and can potentially threaten skin viability. Haematomas are also a good culture medium for organisms and are not penetrated well by antibiotics. Recurrent haemarthroses can lead to joint stiffness and poor function. It is, therefore, extremely important to identify and promptly treat recurrent haemarthroses after TKA. The exact cause of a haemarthrosis cannot always be established as several factors may be responsible. In addition, the routine coagulation profile may be normal, as was the case in our patients. We have found no reference in the literature for an isolated availability defect as a cause of recurrent haemarthroses after TKA.

A PF3 availability defect is an inherited autosomal dominant defect of platelet function characterised by decreased in vitro PF3 availability, but with normal PF3 content and normal platelet aggregation with ADP, adrenaline, collagen, ristocetin and arachidonic acid, resulting in mild bleeding symptoms; ${ }^{23-27}$ it is rare. ${ }^{25}$ Minkoff et al, ${ }^{28}$ found an isolated PF3 availability defect in only three of 316 patients with platelet function defects. However, a PF3 availability defect is more common than once believed. ${ }^{29,30}$ Our unit has previously reported that PF3 availability may be reduced in almost $97 \%$ of patients with platelet function defects, with or without associated defects in platelet aggregation or PF3 content. ${ }^{13}$ The disease typically presents with mild, episodic mucosal bleeds, and is twice as common in women than in men. In contrast, however, our cohort showed only slight gender preference for women and the patients had no previous history of bleeds. This is explained by the fact that the bleeding diathesis in these patients is mild as they have normal platelet aggregation; the bleeding time can be normal in $62 \%$ of these patients. ${ }^{29,31}$

Patients with a PF3 availability defect usually have an uneventful life with recurrent, mild bleeding episodes. Management includes the avoidance of antiplatelet drugs and local application of cold compresses. Administration of platelet concentrates in order to raise the platelet count by $50 \times 10^{9} / \mathrm{L}$ has been used to control major bleeding episodes. ${ }^{32}$ The defect has rarely been shown to improve during pregnancy or with advancing age. ${ }^{33,34}$ With this disease, there is a possible defect in the configurational response of the platelet membrane to ADP activation, which results in a reduced amount of PF3 being made available. Soya bean therapy ( $50 \mathrm{~g}$ per day) has been empirically used to treat this defect with partial success, ${ }^{32,34}$ a treatment which is based upon the concept of increased phospholipid availability for the coagulation cascade, thereby resulting in a correction of the in vitro PF3 availability test.

An inherited platelet function defect is also likely to cause bleeding problems after other major procedures. Some cases of prolonged wound drainage and delayed healing may be caused by this. The condition is easily diagnosed after TKA because of the superficial location of the joint, but it may not be so obvious following surgery of a deepseated joint such as the hip. Consequently, we recommend platelet function tests for all patients who show an unusual bleeding diathesis in the presence of normal coagulation studies and platelet counts.

Questions may be raised about the role of the bleeding time in the diagnosis of these defects pre-operatively. The benefits of using the bleeding time as a pre-operative screening test before all surgical procedures have been previously reported. ${ }^{35}$ However, these authors questioned the costeffectiveness of the test and also concluded that the bleeding time should be used selectively for those patients who, on the basis of history or laboratory evidence, were suspected of being at risk of haemorrhage. This work also found that, even in these patients, a prolonged bleeding time may not always be associated with excessive surgical blood loss. This fact, combined with the observation that almost two-thirds of patients with a PF3 availability defect have a normal bleeding time, suggests that the bleeding time is a poor predictor of haemarthrosis after surgery.

Although the disorder may have only a small global impact, we feel that it may be underdiagnosed. It should be kept in mind while treating migrant populations who have recurrent haemarthroses after TKA.

No benefits in any form have been received or will be received from a commercial party related directly or indirectly to the subject of this article.

\section{References}

1. Kindsfater K, Scott RD. Recurrent hemarthrosis after total knee arthroplasty. J Arthroplasty 1995;10(Suppl):52-5.

2. Oishi CS, Elliott ML, Colwell CW Jr. Recurrent hemarthrosis following a total knee arthroplasty. J Arthroplasty 1995;10(Suppl):56-8.

3. Worland RL, Jessup DE. Recurrent hemarthrosis after total knee arthroplasty. J Arthroplasty 1996;11:977-8.

4. Kindsfater K. Recurrent hemarthrosis after total knee arthroplasty. In: Malek MM ed. Knee surgery: complications, pitfalls and salvage. New York: Springer, 2001: 361-3.

5. Ballard N, Clark K, Callaghan JJ. Recurrent spontaneous hemarthrosis nine years after a total knee arthroplasty: a presentation with pigmented villonodular synovitis J Bone Joint Surg [Am] 1993;75-A:764-7.

6. Ewald FC, Sledge CB, Corson J, Rose RM, Radin EL. Giant cell synovitis associated with failed polyethylene patellar replacements. Orthopedics 1976;115:213-19.

7. Kitridiou RC, Shumacher HR, Sbarbaro TL, Hollander JL. Recurrent hemarthrosis after prosthetic knee arthroplasty: identification of metal particles in synovial fluid. Arthritis Rheum 1969;12:530-7

8. Kaufman R, Tong I, Beardmore T. Prosthetic synovitis: clinical and histologic characteristics. J Rheumatol 1985;12:1066-74.

9. Weissman B, Scott RD, Brick G, Corson J. Radiographic detection of metalinduced synovitis as a complication of arthroplasty of the knee. J Bone Joint Surg [Am] 1991;73-A:1002-7.

10. Mckenna R. Abnormal coagulation in the postoperative period contributing to excessive bleeding. Med Clin North Am 2001;85:277-310.

11. Calabrese S, Giansante C, Sammartini C, Benedetti A. Platelet aggregation and various coagulation parameters in liver cirrhosis. Minerva Med 1986;75:1047-52 (in Italian).

12. Kastun J, Saraya AK. Platelet functions in dysproteinemia. Acta Haematol 1978;59 104-13.

13. Saraya AK, Saxena R, Dhot PS, Choudhry VP, Pati H. Platelet function disorders in North India. Natl Med J India 1954;7:5-7.

14. Tsuda T, Okamoto $Y$, Sakaguchi R, et al. Purpura due to aspirin-induced platelet dysfunction aggravated by drinking alcohol. J Int Med Res 2001;29:374-80.

15. Dacie JV, Lewes SM. Practical hematology. Eighth ed. Edinburgh: Churchill Livingstone, 1994. 
16. Sirridge M. Laboratory evaluation of the bleeding patient. Clin Lab Med 1984;4: 285-301.

17. Spaet TH, Cinatron J. Studies on platelet factor 3 availability. Br J Haematol 1965; 11:296.

18. Kasturi J, Saraya AK, Ramkishan. A study of platelet function: primary thrombopathy. Indian J Med Res 1972;60:567-75.

19. Hardisty RM, Hutton RA. Platelet aggregation and the availability of platelet factor 3. Br J Haematol 1966;12:764-76.

20. Czapek EE, Deykin D, Salzman E, et al. Intermediate syndrome of platelet dysfunction. Blood 1978;52:103-13.

21. Insall JN, Dorr LD, Scott RD, Scott WN. Rationale of the Knee Society clinical rating system. Clin Orthop 1989;248:13-14.

22. Klein $\mathbf{N}$. Choices in the coverage for wound problems following total knee replacement. In: Harnes C, Vince K, Fu F, eds. Techniques in knee surgery. Baltimore: Williams and Wilkins, 2001:280-90.

23. Girolami A, Brunetti A, Fioretti D, Gravina E. Congenital thrombocytopathy (platelet factor 3 defect) with prolonged bleeding but normal platelet adhesiveness and aggregation. Acta Haematol 1973;116:50.

24. Weiss HJ. Abnormalities of platelet function due to defects in the release reaction. Ann NY Acad Sci 1972;102:161-73.

25. Weiss HJ. Platelet physiology and abnormalities of platelet function (second of two parts). N Engl J Med 1975;293:580-5.
26. Weiss HJ, Vicic WJ, Lages BA, Rogers J. Isolated deficiency of platelet procoagulant activity. Am J Med 1979;67:206-13.

27. Zucker S, Mielke CH Jr, Durocher JR, Crosby WH. Oozing and bruising due to abnormal platelet function (thrombocytopathia): a family study of the syndrome. Ann Int Med 1972;76:725-31

28. Minkoff IM, Wu KK, Walasek J, Lightfoot B, Smith-McKearn C. Bleeding disorder due to an isolated platelet factor 3 deficiency. Arch Intern Med 1980;140:366-7.

29. Pati HP, Gupta MK, Saraya AK. Screening tests for platelet function defect: evaluation and recommendation. Haematol Rev 1990;4:1-4.

30. Rao AK, Holmsen H. Congenital disorders of platelet function. Semin Hemato/1986; 23:102-18.

31. Saraya AK, Kasturi J, Kishan R. Platelet factor 3: a simple assay technique. Indian J Med Res 1973;61:676-83.

32. Saxena R, Choudhry VP, Mishra DK, et al. Clinico-haematological profile of isolated PF3 availability defect: therapeutic potential of soya bean. Eur J Haemato/1999; 62:327-31.

33. Manoharan A, Larsen S, Hewitt B. Effect of pregnancy on isolated platelet factor 3 (PF3) defect. Am J Hematol 2001;67:275-6.

34. Saxena R, Choudhry VP, Mishra DK, Kashyap R, Mohanty S. Possible role of soyabean therapy in isolated platelet factor 3 (PF3) availability defect. Am J Hematol 1999;60:170.

35. Barber A, Green D, Galluzzo T, Ts'ao C-H. The bleeding time as a preoperative screening test. Am J Med 1985;78:761-4. 